\title{
The associations between plasma adiponectin, ghrelin levels and cardiovascular risk factors
}

\author{
K M Choi, J Lee ${ }^{1}$, K W Lee, J A Seo, J H Oh, S G Kim, N H Kim, D S Choi and S H Baik \\ Division of Endocrinology and Metabolism, Department of Internal Medicine and ${ }^{1}$ Department of Preventive Medicine, College of Medicine, \\ Korea University, Seoul, Korea
}

(Correspondence should be addressed to S H Baik, Department of Internal Medicine, Korea University Guro Hospital, 80 Guro-Dong, Guro-Gu, Seoul 152-050, South Korea; Email: 103hyun@korea.ac.kr)

\begin{abstract}
Objective: Ghrelin is a recently discovered peptide, which is produced primarily in the stomach. This orexigenic peptide participates not only in the induction of mealtime hunger but also in long-term body weight regulation and energy homeostasis. Adiponectin is a protein secreted by adipocytes, and has been proposed to mediate obesity-related insulin resistance. Moreover, concentrations of adiponectin are reduced in individuals with obesity, insulin resistance and cardiovascular disease. However, human data are sparse about the direct relationship between adiponectin, ghrelin and cardiovascular risk factors including insulin resistance.

Design: Three hundred and thirty-eight elderly Korean women (mean age \pm S.D., $72.3 \pm 5.5$ years) were included in the present study.

Methods: Plasma ghrelin and adiponectin levels were measured by RIA. Anthropometric measurements were taken and a $75 \mathrm{~g}$ oral glucose tolerance test performed. Fasting insulin and lipid profile were measured and insulin resistance was determined using the homeostasis model assessment insulin resistance index (HOMA-R) and the quantitative insulin sensitivity check index.

Results: Plasma adiponectin levels were negatively correlated with central obesity indices such as waist circumference $(r=-0.27, P<0.001)$ and waist-to-hip ratio (WHR) $(r=-0.32$, $P<0.001)$, and with insulin resistance indices such as fasting insulin $(r=-0.17, P=0.004)$ and HOMA-R $(r=-0.13, P=0.035)$. Plasma ghrelin levels were negatively correlated with WHR $(r=-0.12, P=0.03)$, but plasma adiponectin and ghrelin levels were not correlated $(r=0.03$, $P=0.66$ ). Multiple regression analysis showed that adiponectin was associated with WHR, fasting insulin and fasting glucose levels. When ghrelin was used as a dependent variable, only WHR remained in the final fitted model.

Conclusion: Fasting plasma adiponectin and ghrelin levels were found to be associated with central obesity or insulin resistance. However, plasma adiponectin and ghrelin concentrations were not associated with each other in elderly Korean women.
\end{abstract}

European Journal of Endocrinology 150 715-718

\section{Introduction}

Ghrelin is a novel endogenous natural ligand of growth hormone (GH) secretagogue receptor (1), and is recognized an important regulator of $\mathrm{GH}$ secretion and energy homeostasis (2). Ghrelin is an orexigenic peptide that antagonizes leptin action and causes weight gain by increasing food intake and reducing fat utilization in rodents and humans (3-5). Human plasma ghrelin levels increase sharply before and decrease after every meal, which is consistent with a physiological role of ghrelin in mealtime hunger and meal initiation (6). In humans, circulating ghrelin levels are reduced in a chronic state of positive energy balance such as obesity, as well as in an acute state of positive energy balance such as food intake $(6,7)$.
On the other hand, ghrelin levels are increased by fasting (3) and in cachectic patients with anorexia nervosa (8).

Adiponectin has been recently identified as a protein secreted by adipocytes, which are important in metabolic and vascular diseases. Plasma adiponectin concentrations are reduced in obese individuals (9), and in those showing insulin resistance (10). Furthermore, adiponectin concentrations were found to be lower in diabetics than in non-diabetics (9), and were particularly low in subjects with coronary artery disease (11).

Previous studies have reported that ghrelin and adiponectin levels increase after gastric bypass surgery in obese humans (12). Moreover, chronic ghrelin administration to adipocytes strongly impaired adiponectin expression (13). Although both ghrelin and adiponectin 
are associated with obesity and the status of long-term energy homeostasis, human data are scanty about the relationship between adiponectin, ghrelin and cardiovascular risk factors, including insulin resistance.

In this study, we evaluated a relationship between plasma adiponectin, produced by adipose tissue, and plasma ghrelin, produced by the stomach. Accordingly, we tried to find an interaction between stomach and adipose tissue in the control of energy homeostasis. In addition, we examined the effects of cardiovascular risk factors such as obesity and insulin resistance on plasma adiponectin and ghrelin levels in elderly Korean women.

\section{Materials and methods}

This study was conducted in regional senior welfare centers of the Seoul Metropolitan Government by medical personnel of Korea University. A total of 338 elderly Korean women (between 61 and 89 years of age) who had no apparent disease history participated in this study. An informed consent has given by all subjects before participating in the study, which was approved by the ethical committee of our institutions. After history taking, a $75 \mathrm{~g}$ oral glucose tolerance test was been performed. Blood samples were drawn after an overnight fast and immediately centrifuged. Blood chemistry was measured at the laboratory of the Korea University Guro Hospital (Seoul, Korea). Serum total cholesterol, triglycerides and high-density lipoprotein (HDL) cholesterol were determined by enzymatic methods with a chemistry analyzer (Hitachi 747, Tokyo, Japan). Low-density lipoprotein (LDL) cholesterol was calculated using the formula of Friedewald et al. (14). Plasma glucose was measured using the glucose oxidase method, while insulin was measured using a human insulin-specific RIA kit (Linco Research Inc., St Charles, MO, USA), which had reactivity of less than $0.2 \%$ with human proinsulin. Insulin resistance was assessed by determining the homeostasis model assessment insulin resistance index (HOMA-R) (15) and the quantitative insulin sensitivity check index (QUICKI) (16). HOMA-R was calculated as (fasting glucose $(\mathrm{mmol} / \mathrm{l}) \times$ fasting insulin $(\mu \mathrm{U} / \mathrm{ml}) / 22.5)$, and QUICKI as $(1 /(\log$ fasting insulin $(\mu \mathrm{U} / \mathrm{ml})+\log$ fasting glucose $(\mathrm{mg} / \mathrm{dl}))$. Plasma adiponectin was measured using a human adiponectin RIA kit (Linco Research) (human adiponectin sensitivity $1 \mathrm{ng} / \mathrm{ml}$ using a $100 \mu \mathrm{l}$ sample size; intra-assay coefficient of variation (CV) $8.7 \%$ ). A human ghrelin (total) RIA kit (Linco Research) (human ghrelin sensitivity $100 \mathrm{pg} / \mathrm{ml}$ using a $100 \mu \mathrm{l}$ sample size; intra-assay CV $7.5 \%$ ) was used for measuring the plasma ghrelin level.

Data were expressed as means \pm S.D. (geometric mean and its S.D. for variables not normally distributed are presented). Correlation analysis between plasma adiponectin, ghrelin and risk factor variables of cardiovascular disease was performed. Multiple linear regression models using adiponectin or ghrelin as dependent variables were conducted to obtain relative contributions of each variable to the outcome variable. Significant independent variables were chosen by using a stepwise variable selection method with $\alpha=0.15$. A value of $P<0.05$ was used to indicate statistical significance. Data were analyzed using SPSS for Windows (version 10.0; SPSS Inc., Chicago, IL, USA).

\section{Results}

The characteristics of study subjects were summarized in Table 1. Study subjects were elderly women aged over 60 years and relatively overweight (mean body

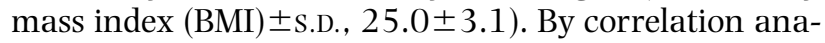
lysis, plasma adiponectin levels were found to be negatively correlated with central obesity parameters such as waist circumference $(r=-0.27, P<0.001)$ and waist-to-hip ratio (WHR) $(r=-0.32, P<0.001)$, as well as with insulin resistance parameters such as fasting insulin $(r=-0.17, P=0.004)$ and HOMA-R $(r=-0.13, P=0.035)$. Plasma ghrelin levels correlated negatively with WHR $(r=0.12, P=0.03)$. However, plasma adiponectin and ghrelin concentrations were not correlated $(r=0.03, P=0.66)$. Stepwise multiple regression analyses were performed with adiponectin or ghrelin as dependent variables. Age, systolic and diastolic blood pressure, BMI, WHR, total cholesterol, HDL cholesterol, triglycerides, LDL cholesterol, fasting and post-load $2 \mathrm{~h}$ glucose, fasting insulin, HOMA-R, QUICKI, adiponectin and ghrelin were employed as independent variables (Table 2). Multiple regression analysis showed that adiponectin was associated with WHR, fasting insulin and fasting glucose levels. On the other hand, WHR was the only

Table 1 Characteristics of study subjects.

\begin{tabular}{lc}
\hline Age (years) & $72.3 \pm 5.5$ \\
\hline Systolic blood pressure $(\mathrm{mmHg})$ & $141.2 \pm 20.3$ \\
Diastolic blood pressure $(\mathrm{mmHg})$ & $84.4 \pm 10.1$ \\
BMI & $25.0 \pm 3.1$ \\
Waist circumference $(\mathrm{cm})$ & $86.4 \pm 8.9$ \\
WHR & $0.92 \pm 0.08$ \\
Total cholesterol $(\mathrm{mmol} / \mathrm{l})$ & $5.3 \pm 0.9$ \\
HDL cholesterol $(\mathrm{mmol} / \mathrm{l})$ & $1.5 \pm 0.3$ \\
Triglycerides $\left(\mathrm{mmol} / \mathrm{l}^{*}\right.$ & $1.4 \pm 1.6$ \\
LDL cholesterol $(\mathrm{mmol} / \mathrm{l})$ & $3.1 \pm 0.8$ \\
Fasting glucose $(\mathrm{mmol} / \mathrm{l})$ & $5.6 \pm 1.1$ \\
Post-load $2 \mathrm{~h} \mathrm{glucose}(\mathrm{mmol} / \mathrm{l})$ & $7.7 \pm 2.5$ \\
Fasting insulin $(\mu \mathrm{U} / \mathrm{ml})$ & $8.9 \pm 5.0$ \\
HOMA-R & $2.2 \pm 1.4$ \\
QUICKI & $0.35 \pm 0.06$ \\
Adipnectin $(\mathrm{ng} / \mathrm{ml})^{*}$ & $12.8 \pm 2.3$ \\
Ghrelin $(\mathrm{pg} / \mathrm{ml})$ & $1907 \pm 547$ \\
\hline
\end{tabular}

* Geometric mean \pm geometric S.D. 
Table 2 Correlations among adiponectin, ghrelin and the risk factor variables of cardiovascular disease.

\begin{tabular}{|c|c|c|c|c|}
\hline & \multicolumn{2}{|c|}{ Adiponectin } & \multicolumn{2}{|c|}{ Ghrelin } \\
\hline & $r$ & $P$ & $r$ & $P$ \\
\hline Age & -0.030 & 0.619 & -0.046 & 0.397 \\
\hline Systolic blood pressure & 0.024 & 0.693 & -0.001 & 0.981 \\
\hline Diastolic blood pressure & 0.051 & 0.395 & -0.016 & 0.772 \\
\hline BMI & 0.011 & 0.857 & 0.023 & 0.682 \\
\hline Waist circumference & -0.272 & $<0.001$ & -0.049 & 0.370 \\
\hline WHR & -0.323 & $<0.001$ & -0.119 & 0.030 \\
\hline Total cholesterol & 0.041 & 0.495 & -0.019 & 0.730 \\
\hline HDL cholesterol & 0.048 & 0.426 & 0.035 & 0.518 \\
\hline Triglycerides & -0.030 & 0.621 & -0.062 & 0.260 \\
\hline LDL cholesterol & 0.053 & 0.383 & -0.013 & 0.816 \\
\hline Fasting glucose & 0.126 & 0.035 & 0.091 & 0.096 \\
\hline Post-load $2 \mathrm{~h}$ glucose & 0.078 & 0.230 & 0.053 & 0.374 \\
\hline Fasting insulin & -0.173 & 0.004 & 0.014 & 0.803 \\
\hline HOMA-R & -0.126 & 0.035 & 0.030 & 0.587 \\
\hline QUICKI & 0.077 & 0.199 & 0.002 & 0.971 \\
\hline Adiponectin & 1.000 & - & 0.026 & 0.661 \\
\hline Ghrelin & 0.026 & 0.661 & 1.000 & - \\
\hline
\end{tabular}

significant independent variable in multiple regression analysis using ghrelin as a dependent variable.

\section{Discussion}

The peripheral or central administration of ghrelin to rodents has been found to stimulate short-term food intake as potently as any known compound (17). This orexigenic action is mediated via the hypothalamic arcuate nucleus, which co-expresses neuropeptide $\mathrm{Y}$ and agouti-related protein (2). Several studies have suggested that ghrelin may participate not only in mealtime hunger and meal initiation, but also in long-term body weight regulation (18). Moreover, continuous or repeated ghrelin administration increases body weight $(3,19)$. These observations distinguish ghrelin from cholecystokinin, which can alter meal patterns, but not body weight when injected long-term (20). The blockade of endogenous ghrelin signaling in the brain can reduce spontaneous food intake and body weight $(21,22)$. In addition, it has been reported that ghrelin administration not only increases food intake but also decreases metabolic rate (17) and fat catabolism (3). These studies intimate that ghrelin has an important role in long-term energy homeostasis. Indeed, elevated ghrelin levels were found during weight loss resulting from caloric restriction (23), anorexia nervosa (8) and cancer anorexia (24). These results suggest a role for ghrelin in the adaptive response to body weight changes.

Previous studies reported that ghrelin reduces insulin secretion in the isolated rat pancreas and in humans $(25,26)$. Tschop et al. (27) found a negative correlation between plasma ghrelin and insulin concentrations. In contrast, no relationship was found between plasma ghrelin and insulin concentrations in a recent study (28). In the present study, plasma ghrelin levels were only associated with central obesity parameters such as WHR.

We measured only fasting ghrelin levels in our study. Cummings et al. (6) reported that plasma ghrelin levels nearly doubled immediately before each meal, and fell within $1 \mathrm{~h}$ after eating, a pattern which is the reciprocal of that of insulin levels. They suggested that a single measurement of plasma ghrelin before breakfast might serve as a surrogate for the estimation of overall ghrelin levels, because this measure correlated strongly with $24 \mathrm{~h}$ integrated area under the curve values (6).

Recently, it was found that adipose tissue is not merely an inert energy storage depot, but rather an active organ which secretes various hormones and metabolites that are thought to regulate energy metabolism and insulin sensitivity (29). Both excess adipose tissue in obesity and a lack of adipose tissue in a lipodystrophic state were associated with insulin resistance and type 2 diabetes in human and animal studies $(30,31)$. Adiponectin has been recently identified as a protein secreted by adipocytes, which are important in metabolic and vascular diseases. Adiponectin is exclusively expressed in adipose tissue and released into the circulation (32). Paradoxically, obese individuals have reduced plasma adiponectin concentrations (10). Decreased adiponectin concentrations were also reported in individuals with type 2 diabetes (33), insulin resistance (9) or cardiovascular disease (11). Interestingly, chronic administration of adiponectin prevented a high-fat diet-induced weight gain, despite the fact that food consumption was unaffected (34).

In the present study, we evaluated an inter-relationship between ghrelin and adiponectin. Previous studies have reported that both ghrelin and adiponectin are associated with obesity and the status of long-term energy homeostasis. Holdstock et al. (12) reported that ghrelin and adiponectin levels increased after gastric bypass surgery in obese humans. Their study, in agreement with the present study, found no correlation between ghrelin and adiponectin. In addition, they reported correlations between insulin and ghrelin in univariate analysis. However, we could not find such a relationship in our study. Their study included younger subjects with higher BMIs than ours.

In the study of Ott et al. (13), chronic ghrelin administration to adipocytes strongly impaired adiponectin expression, although it did not significantly alter the gene expression of thermogenic uncoupling protein-1. Therefore, we hypothesized an interaction between ghrelin produced by the stomach and adiponectin produced by adipose tissue. However, although plasma adiponectin and ghrelin concentrations are individually related to obesity indices or insulin resistance indices, their levels were not found to be associated with each other in elderly Korean women. 


\section{References}

1 Kojima M, Hosoda H, Date Y, Nakazato M, Matsuo H \& Kangawa K. Ghrelin is a growth-hormone-releasing acylated peptide from stomach. Nature $1999 \mathbf{4 0 2} 656-660$.

2 Horvath TL, Diano S, Sotonyi P, Heiman M \& Tschop M. Minireview: ghrelin and the regulation of energy balance - a hypothalamic perspective. Endocrinology 2001142 4163-4169.

3 Tschop M, Smiley DL \& Heiman ML. Ghrelin induces adiposity in rodents. Nature $2000 \mathbf{4 0 7} 908-913$.

4 Wren AM, Small CJ, Ward HL, Murphy KG, Dakin CL, Taheri S et al. The novel hypothalamic peptide ghrelin stimulates food intake and growth hormone secretion. Endocrinology 2000141 4325-4328.

5 Wren AM, Seal LJ, Cohen MA, Brynes AE, Frost GS, Murphy KG et al. Ghrelin enhances appetite and increases food intake in humans. Journal of Clinical Endocrinology and Metabolism 2001 865992.

6 Cummings DE, Purnell JQ, Frayo RS, Schmidova K, Wisse BE \& Weigle DS. A preprandial rise in plasma ghrelin levels suggests a role in meal initiation in humans. Diabetes $2001 \mathbf{5 0}$ 1714-1719.

7 Tschop M, Wawarta R, Riepl RL, Friedrich S, Bidlingmaier M, Landgraf $\mathrm{R}$ et al. Post-prandial decrease of circulating human ghrelin levels. Journal of Endocrinological Investigation $20012 \mathbf{2}$ RC19-RC21.

8 Otto B, Cuntz U, Fruehauf E, Wawarta R, Folwaczny C, Riepl RL et al. Weight gain decreases elevated plasma ghrelin concentrations of patients with anorexia nervosa. European Journal of Endocrinology 2001145 669-673.

9 Weyer C, Funahashi T, Tanaka S, Hotta K, Matsuzawa Y, Pratley RE et al. Hypoadiponectinemia in obesity and type 2 diabetes: close association with insulin resistance and hyperinsulinemia. Journal of Clinical Endocrinology and Metabolism $2001 \mathbf{8 6}$ 1930-1935.

10 Arita Y, Kihara S, Ouchi N, Takahashi M, Maeda K, Miyagawa J et al. Paradoxical decrease of an adipose-specific protein, adiponectin, in obesity. Biochemical and Biophysical Research Communications 1999257 79-83.

11 Ouchi N, Kihara S, Arita Y, Maeda K, Kuriyama H, Okamoto Y et al Novel modulator for endothelial adhesion molecules: adipocyte-derived plasma protein adiponectin. Circulation 1999100 2473-2476.

12 Holdstock C, Engstrom BE, Ohrvall M, Lind L, Sundbom M \& Karlsson FA. Ghrelin and adipose tissue regulatory peptides: effect of gastric bypass surgery in obese humans. Journal of Clinical Endocrinology and Metabolism $2003 \mathbf{8 8} 3177-3183$.

13 Ott V, Fasshauer M, Dalski A, Meier B, Perwitz N, Klein HH et al. Direct peripheral effects of ghrelin include suppression of adiponectin expression. Hormone and Metabolic Research 200234 640-645.

14 Friedewald WT, Levy RI \& Fredrickson DS. Estimation of the concentration of low-density lipoprotein cholesterol in plasma, without use of the preparative ultracentrifuge. Clinical Chemistry 1972 18 499-502.

15 Matthews DR, Hosker JP, Rudenski AS, Naylor BA, Treacher DF \& Turner RC. Homeostasis model assessment: insulin resistance and beta-cell function from fasting plasma glucose and insulin concentrations in man. Diabetologia $1985 \mathbf{2 8} 412-419$.

16 Katz A, Nambi SS, Mather K, Baron AD, Follmann DA, Sullivan G et al. Quantitative insulin sensitivity check index: a simple, accurate method for assessing insulin sensitivity in humans. Journal of Clinical Endocrinology and Metabolism 200085 2402-2410.

17 Asakawa A, Inui A, Kaga T, Yuzuriha H, Nagata T, Ueno N et al. Ghrelin is an appetite-stimulatory signal from stomach with structural resemblance to motilin. Gastroenterology $2001 \mathbf{1 2 0}$ $337-345$.

18 Cummings DE \& Shannon MH. Roles for ghrelin in the regulation of appetite and body weight. Archives of Surgery $2003 \mathbf{1 3 8}$ 389-396.

19 Wren AM, Small CJ, Abbott CR, Dhillo WS, Seal LJ, Cohen MA et al. Ghrelin causes hyperphagia and obesity in rats. Diabetes 200150 2540-2547.

20 West DB, Fey D \& Woods SC. Cholecystokinin persistently suppresses meal size but not food intake in free-feeding rats. American Journal of Physiology 1984246 R776-R787.

21 Nakazato M, Murakami N, Date Y, Kojima M, Matsuo H, Kangawa $\mathrm{K}$ et al. A role for ghrelin in the central regulation of feeding. Nature 2001409 194-198.

22 Murakami N, Hayashida T, Kuroiwa T, Nakahara K, Ida T, Mondal MS et al. Role for central ghrelin in food intake and secretion profile of stomach ghrelin in rats. Journal of Endocrinology $2002 \mathbf{1 7 4}$ 283-288.

23 Cummings DE, Weigle DS, Frayo RS, Breen PA, Ma MK, Dellinger $\mathrm{EP}$ et al. Plasma ghrelin levels after diet-induced weight loss or gastric bypass surgery. New England Journal of Medicine 2002 346 1623-1630.

24 Wisse BE, Frayo RS, Schwartz MW \& Cummings DE. Reversal of cancer anorexia by blockade of central melanocortin receptors in rats. Endocrinology $20011423292-3301$.

25 Egido EM, Rodriguez-Gallardo J, Silvestre RA \& Marco J. Inhibitory effect of ghrelin on insulin and pancreatic somatostatin secretion. European Journal of Endocrinology $2002146241-244$.

26 Broglio F, Arvat E, Benso A, Gottero C, Muccioli G, Papotti M et al. Ghrelin, a natural GH secretagogue produced by the stomach, induces hyperglycemia and reduces insulin secretion in humans. Journal of Clinical Endocrinology and Metabolism 2001 86 5083-5086.

27 Tschop M, Weyer C, Tataranni PA, Devanarayan V, Ravussin E \& Heiman ML. Circulating ghrelin levels are decreased in human obesity. Diabetes 200150 707-709.

28 Gokcel A, Gumurdulu Y, Kayaselcuk F, Serin E, Ozer B, Ozsahin AK et al. Helicobacter pylori has no effect on plasma ghrelin levels. European Journal of Endocrinology 2003 148 423-426.

29 Havel PJ. Control of energy homeostasis and insulin action by adipocyte hormones: leptin, acylation stimulating protein, and adiponectin. Current Opinion in Lipidology $20021351-59$.

$30 \mathrm{Kahn}$ BB \& Flier JS. Obesity and insulin resistance. Journal of Clinical Investigation $2000 \mathbf{1 0 6} 473-481$.

31 Ganda OP. Lipoatrophy, lipodystrophy, and insulin resistance. Annals of Internal Medicine 2000133 304-306.

32 Maeda K, Okubo K, Shimomura I, Funahashi T, Matsuzawa Y \& Matsubara K. cDNA cloning and expression of a novel adipose specific collagen-like factor, apM1 (AdiPose Most abundant Gene transcript 1). Biochemical and Biophysical Research Communications $1996221286-289$.

33 Hotta K, Funahashi T, Arita Y, Takahashi M, Matsuda M, Okamoto Y et al. Plasma concentrations of a novel, adipose-specific protein, adiponectin, in type 2 diabetic patients. Arteriosclerosis, Thrombosis, and Vascular Biology 200020 1595-1599.

34 Fruebis J, Tsao TS, Javorschi S, Ebbets-Reed D, Erickson MR, Yen FT et al. Proteolytic cleavage product of 30-kDa adipocyte complement-related protein increases fatty acid oxidation in muscle and causes weight loss in mice. PNAS 200198 2005-2010.

Received 3 September 2003

Accepted 12 February 2004 